\title{
SIMPLIFIED PREDICTIVE TORQUE CONTROL SCHEME FOR OPEN END WINDING INDUCTION MOTOR USING ANFIS CONTROLLER
}

\author{
M. ANKARAO ${ }^{1}$, L. SIREESHA ${ }^{2}$, M. VIJAYA KUMAR ${ }^{3} \&$ J. SREENIVASULU ${ }^{4}$ \\ ${ }^{I}$ Assistant Professor, JNTUA College of Engineering (Autonomous), Ananthapuramu, Andhra Pradesh, India \\ Student, JNTUA College of Engineering (Autonomous), Ananthapuramu, Andhra Pradesh, India \\ Professor, JNTUA College of Engineering (Autonomous), Ananthapuramu, Andhra Pradesh, India \\ Assistant Professor, JNTUA College of Engineering (Autonomous), Ananthapuramu, Andhra Pradesh, India
}

\begin{abstract}
This paper presents a Simplified Predictive Torque Control Scheme for Open end winding induction motor drive with two inverters using ANFIS controller. The flux weighting factor can be removed and the reactive torque control is used in the place of flux control objective in simplified PTC. The two control objectives torque and flux are represented with same units and thus flux weighting factor can be eliminated in the cost function. It results minimum torque and flux ripple and transient current is reduced. The various performancesusing PI and ANFIS controller of simplified PTC for dual inverter fed OEWIMis validated through MATLAB/SIMULINK.
\end{abstract}

KEYWORDS: Dual Inverter Fed OEWIM, Predictive Torque Control, Reactive Torque Control, ANFIS Controller

Received: Jun 09, 2020; Accepted: Jun 29, 2020; Published: Jul 31, 2020; Paper Id.: IJMPERDJUN2020552

\section{INTRODUCTION}

Now a daysfor many industrial drive applications, Induction motor drives fed with voltage source inverter became more popular. By increasing number of voltage vectors the accurate control of motor drive is possible. With multilevel voltage source inverters (MLI)more number of voltage vectors are obtained. In [1], Different types of multi level inverters with reduced device count werepresented. In [2], various topologies for multilevel Converters such as Neutral point clamped, cascaded H-bridge, flying capacitors and most widely used modulation methods are studied. While different types of multilevel inverters are available, we use dual inverter OEWIM configuration as it provides more advantages such as: simple because of the absence of clamping diodes, easy accessibility of two-level VSIs for multilevel inversion. The drive dynamic performance can be enhanced through several control methods. There are some disadvantages in FOC like complicated control structure and reference frame transformations. The Field Oriented Control for OEWIM is presented in [4]. The Direct torque control technique has overcome these limitations for the drive [5]. The limitations of DTC are presented in [6]-[8]. The Direct Torque Control technique for two inverters fed OEWIM is presented in [9].

Model Predictive Control is used in control technique and is enforced for the different applications of drive [10]. Finite control set MPCand Continuous control set MPC are the two sections of MPC where Predictive Torque Control (PTC) is the section in FS-MPC. PTC becomes very famous due to the merits like straightforward structure, improved torque and flux regulation, simple control.

The PTC management mechanism is a minimization of cost functions. The cost function comprises torque and flux control objectiveswhich has different units, hence a corresponding balance weighting factor is provided, 
which determines the motor drive performance [11].By replacing flux control objective with reactive torque control, the weighting factor can be eliminated in simplified PTC.

This paper contains modelling of OEWIM with dual inverter and also the voltage space vector allocations. The simplified PTC scheme is enforced for the dual inverter fed OEWIM drive, where the weighting element of the cost function is completely removed. Based on the selection of adjacent voltage vectors number of prediction voltage vectors is reduced, thereby decreasing calculating control mechanism stress. The simplified PTC scheme of OEWIM is evaluated with PI and ANFIS controller through simulation. The paper structured as, Section II with the mathematical modelling of two inverters fed OEWIM drive. Section III sets out specific details about the operation of simplified PTC. The section IV has simplified PTC with ANFIS controller is specified. The section V gives the effectiveness of simplified PTC with ANFIS controller over simplified PTC with PI controller through simulation. Section VI, represents the conclusions of this paper.

\section{DUAL INVERTER FED OEWIM MATHEMATICAL EQUATIONS}

The pole voltages of voltage source inverters are characterized by equations (1) and (2) from Fig.1. The pole voltages can be calculated with negative rails of their corresponding VSIs.The dc link voltages of two inverters are managed as 2:1 ratio for achieving four level inversion.Thence, $\mathrm{C}_{1} \mathrm{~V}_{\mathrm{dc}}$ is the input voltage provided to the VSI- 1 , where $\mathrm{C}_{1}$ is $2 / 3$ and voltage across VSI-1 is $2 \mathrm{~V}_{\mathrm{dc}} / 3 . \mathrm{C}_{2} \mathrm{~V}_{\mathrm{dc}}$ is the voltage given to the VSI-2, where $\mathrm{C}_{2}$ is $1 / 3$ and hence the voltage across VSI-2 is $\mathrm{V}_{\mathrm{dc}} / 3$. The switching pulses like $S_{a}, S_{b}, S_{c}, S_{a}{ }^{\prime}, S_{b}{ }^{\prime}, S_{c}{ }^{\prime}$ are given to upper switches $\left(S_{1}, S_{3}, S_{5}, S_{1}, S_{3}, S_{5}{ }^{\prime}\right)$ of dual inverter.

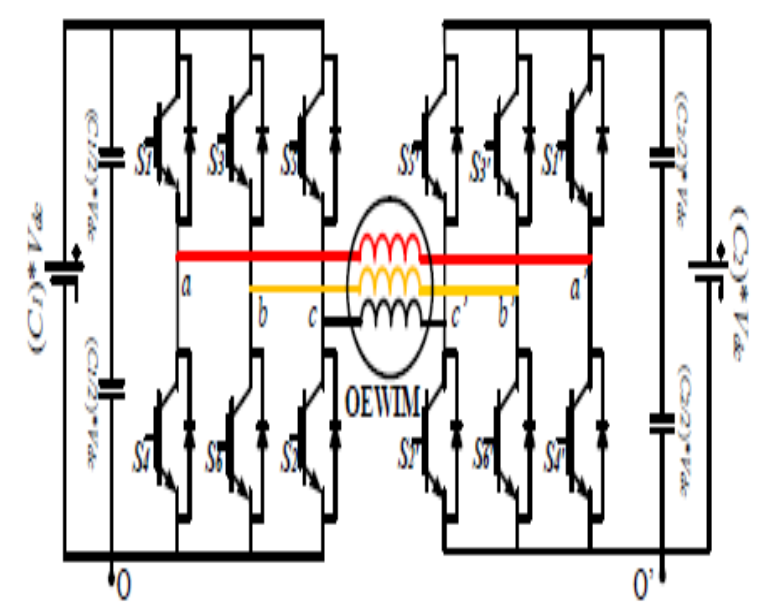

Figure 1: OEWIM model

$$
\begin{aligned}
& \left(\begin{array}{l}
\boldsymbol{V}_{\boldsymbol{a} \boldsymbol{o}} \\
\boldsymbol{V}_{\boldsymbol{b o}} \\
\boldsymbol{V}_{\boldsymbol{c o}}
\end{array}\right)=\left(\begin{array}{l}
\boldsymbol{S}_{\boldsymbol{a}} \\
\boldsymbol{S}_{\boldsymbol{b}} \\
\boldsymbol{S}_{\boldsymbol{c}}
\end{array}\right) * \mathrm{C}_{1} \mathrm{~V}_{\mathrm{dc}} \\
& \left(\begin{array}{l}
\boldsymbol{V}_{\boldsymbol{a}^{\prime} \boldsymbol{o}^{\prime}} \\
\boldsymbol{V}_{\boldsymbol{b}^{\prime} \boldsymbol{o}^{\prime}} \\
\boldsymbol{V}_{\boldsymbol{c}^{\prime} \boldsymbol{o}^{\prime}}
\end{array}\right)=\left(\begin{array}{l}
\boldsymbol{S}_{\boldsymbol{a}^{\prime}} \\
\boldsymbol{S}_{\boldsymbol{b}^{\prime}} \\
\boldsymbol{S}_{\boldsymbol{c}^{\prime}}
\end{array}\right) * \mathrm{C}_{2} \mathrm{~V}_{\mathrm{dc}}
\end{aligned}
$$

Where $C_{1}$ and $C_{2}$ are constants which are assigned as $C_{1}=2 / 3$ and $C_{2}=1 / 3$

The difference of dual inverter pole voltages is stated by equation (3). The voltage enforced to OEWIM phases are givenby (6). 


$$
\begin{aligned}
& \left(\begin{array}{l}
\delta V_{a a^{\prime}} \\
\delta V_{b b^{\prime}} \\
\delta V_{c c^{\prime}}
\end{array}\right)=\left(\begin{array}{l}
V_{a o}-V_{a^{\prime} o^{\prime}} \\
V_{b o}-V_{b^{\prime} o^{\prime}} \\
V_{c o}-V_{c^{\prime} o^{\prime}}
\end{array}\right) \\
& \left(\begin{array}{l}
\boldsymbol{\delta} \mathbf{V}_{\mathbf{a a}^{\prime}} \\
\boldsymbol{\delta} \mathbf{V}_{\mathbf{b b}^{\prime}} \\
\boldsymbol{\delta} \mathbf{V}_{\mathbf{c c ^ { \prime }}}
\end{array}\right)=\left(\begin{array}{c}
\mathbf{V}_{\mathbf{a a}^{\prime}} \\
\mathbf{V}_{\mathbf{b b}^{\prime}} \\
\mathbf{V}_{\mathbf{c c}}
\end{array}\right)+\left(\begin{array}{c}
\mathbf{V}_{\mathbf{z}} \\
\mathbf{V}_{\mathbf{z}} \\
\mathbf{V}_{\mathbf{z}}
\end{array}\right) \\
& \mathrm{V}_{\mathrm{z}}=\frac{1}{3}\left(\delta V_{a a^{\prime}}+\delta V_{b b^{\prime}}+\delta V_{c c^{\prime}}\right) \\
& \left(\begin{array}{l}
V_{a a^{\prime}} \\
V_{b b^{\prime}} \\
V_{c c^{\prime}}
\end{array}\right)=\left(\begin{array}{ccc}
\frac{2}{3} & \frac{-1}{3} & \frac{-1}{3} \\
\frac{-1}{3} & \frac{2}{3} & \frac{-1}{3} \\
\frac{-1}{3} & \frac{-1}{3} & \frac{2}{3}
\end{array}\right) *\left(\begin{array}{l}
\delta V_{a a^{\prime}} \\
\delta V_{b b^{\prime}} \\
\delta V_{c c^{\prime}}
\end{array}\right)
\end{aligned}
$$

The OEWIM is modelled in stator reference frame. The voltage, flux linkage of rotor and stator are expressed in equations (7)-(10). Electromagnetic torque and motor-load torque are expressed by the equations (11)-(12).

$$
\begin{aligned}
& \mathrm{V}_{\mathrm{s}}=\mathrm{R}_{\mathrm{s}} \mathrm{i}_{\mathrm{s}}+\mathrm{p} \lambda_{\mathrm{s}} \\
& 0=\mathrm{R}_{\mathrm{r}} \mathrm{i}_{\mathrm{r}}+\mathrm{p} \lambda_{\mathrm{r}}-\mathrm{j} \omega_{r} \lambda_{r} \\
& \lambda_{\mathrm{s}}=\boldsymbol{L}_{\boldsymbol{s}} \boldsymbol{i}_{\boldsymbol{s}}+\boldsymbol{L}_{\boldsymbol{m}} \boldsymbol{i}_{\boldsymbol{r}} \\
& \lambda_{\mathrm{r}}=\boldsymbol{L}_{\boldsymbol{m}} \boldsymbol{i}_{\boldsymbol{s}}+\boldsymbol{L}_{\boldsymbol{r}} \boldsymbol{i}_{\boldsymbol{r}} \\
& \mathrm{T}_{\mathrm{m}}=\frac{3}{2} \frac{\boldsymbol{p}}{2}\left(\boldsymbol{i m a g}\left(\overline{\lambda_{s}} * \boldsymbol{i}_{\boldsymbol{s}}\right)\right) \\
& \mathrm{T}_{\mathrm{m}}-\mathrm{T}_{\mathrm{l}}=\mathrm{J} \frac{d \omega_{m}}{d t}
\end{aligned}
$$

The rotor and stator terms are described with subscript " $r$ " and "s" in equation (9) and (10). In a machine P represents the number of poles and moment of inertia is denoted by $\mathbf{J}$. $\boldsymbol{\omega}_{\mathbf{m}}$ and $\boldsymbol{\omega}_{\mathbf{r}}$ represents motor mechanical and electrical speed. The flux space vector $\left(\lambda_{\mathrm{s}}\right)$ andcurrent space vector $\left(\mathrm{i}_{\mathrm{s}}\right)$ are called as state variables of machine. Stator flux vector and current vector is given by (13) and (14) equationsrespectively.

$\frac{d \lambda_{s}}{d t}=V_{s}+R i_{s}$

$\frac{d i_{s}}{d t}=R_{1}\left(R_{2} \lambda_{s}-R_{3} i_{s}+K_{r}\left(V_{s}-j \omega_{r} \lambda_{r}\right)+K_{r} R i_{s}+\frac{\mathrm{j} \omega_{r} i_{s}}{R_{1}}\right)$

Where $\mathrm{R}=-\mathrm{R}_{\mathrm{s}}, \mathrm{R}_{1}=\frac{L_{m}}{L_{s} L_{r}-L_{m}^{2}}, \mathrm{R}_{2}=\frac{R_{r}}{L_{m}}, \mathrm{R}_{3}=\frac{L_{s} R_{r}}{L_{m}}, \mathrm{P}=\frac{d}{d t}, \mathrm{~K}_{\mathrm{r}}=\frac{L_{r}}{L_{m}}, \mathrm{~V}_{\mathrm{s}}=\mathrm{V}_{\mathrm{s} \alpha}+\mathrm{V}_{\mathrm{s} \beta}, \mathrm{i}_{\mathrm{s}}=\mathrm{i}_{\mathrm{s} \alpha}+\mathrm{i}_{\mathrm{s} \beta} \lambda_{\mathrm{s}}=\lambda_{\mathrm{s} \alpha}+\lambda_{\mathrm{s} \beta}$

\section{SIMPLIFIED PTC USING PI CONTROLLER}

The required inputs for the simplified PTC are stator current, real and reactive torque, sensed motor speed. Speed PI controller generate real torque by comparing the reference speed with sensed speed, giving error to the PI controller. It will maintain the speed of motor nearer to the mention speed. By using equations (13)-(14) the machine model can be characterized in a discrete manner by implementing Forward Euler's method. 




Figure 2: Simplified PTC using PI controller

This can be illustrated as

$$
\frac{\mathrm{dz}}{\mathrm{dt}}=\frac{\mathrm{z}(\mathrm{k}+1)-\mathrm{z}(\mathrm{k})}{\mathrm{T}_{\mathrm{s}}}
$$

Where: ' $k$ ' is present sampling state, ' $T s$ ' is sampling period and ' $Z$ ' is any state variable

The basic steps in this simplified PTC are given as follows

\section{Step1: The Measure and Estimation}

The motor speed and dc link voltage are precisely measured and with the motor phases stator currents $i_{a}$, $i_{b}$ and $i_{c}$ are obtained directly. The 3- $\varnothing$ currents are transformed into $2-\varnothing$ currents $\left(i_{\alpha}, i_{\beta}\right)$ by using Clarke's transformation for reducing the complexity. All the measured variables voltage, speed, current are given to the PTC algorithm. The stator flux is obtained by knowing instant sample state $(\mathrm{k})$ and previous sample state $(\mathrm{k}-1)$ variables, which is given as

$$
\lambda_{s}(k)=\lambda_{s}(k-1)+T_{s}\left(\left(V_{s}(k-1)+R i_{s}(k-1)\right)\right)
$$

\section{Step2: The Prediction}

In a given dual inverter configuration for all the active voltage space vectors, the stator current and flux can be forecasted with one step ahead $[\mathrm{k}+1]$. Both inverters are fed with unequal voltages and from VSI-1, VSI-2 the voltage space vectors produced $\left(\mathrm{V}_{\mathrm{s} 1}\right.$ and $\left.\mathrm{V}_{\mathrm{s} 2}\right)$. The effective voltage space vector applied for the machine will be given by (19).

$\mathrm{V}_{\mathrm{s} 1}=\left(\frac{2}{3}\right)\left(\mathrm{C}_{1} * \mathrm{~V}_{\mathrm{dc}}\right)\left(\mathrm{S}_{\mathrm{a}}+\mathrm{S}_{\mathrm{b}} \mathrm{e}^{\mathrm{j} 2 \Pi / 3}+\mathrm{S}_{\mathrm{c}} \mathrm{e}^{\mathrm{j} 4 \Pi / 3}\right)$

$\mathrm{V}_{\mathrm{s} 2}=\left(\frac{2}{3}\right)\left(\mathrm{C}_{2} * \mathrm{~V}_{\mathrm{dc}}\right)\left(\mathrm{S}_{\mathrm{a}}^{\prime}+\mathrm{S}_{\mathrm{b}}^{\prime} \mathrm{e}^{\mathrm{j} 2 \Pi / 3}+\mathrm{S}_{\mathrm{c}}^{\prime} \mathrm{e}^{\mathrm{j} 4 \Pi / 3}\right)$

$\mathrm{V}_{\mathrm{s}}=\mathrm{V}_{\mathrm{s} 1}-\mathrm{V}_{\mathrm{s} 2}$

They are 64 possible dual inverter switching states. Among these states, there are 37 effective states which are grouped into small, medium, and large group. Voltage vector $\left(\mathrm{V}_{1^{-}} \mathrm{V}_{6}\right)$ is small group, $\left(\mathrm{V}_{7}-\mathrm{V}_{18}\right)$ is medium group and $\left(\mathrm{V}_{19^{-}}\right.$ $\mathrm{V}_{36}$ ) is large group.

The table shown below gives the realisation in stationary reference frame and effective switching states.For the 37 voltage space vector, the stator current and flux can be forecasted using sample state variable. The forecasted stator flux 
and current are given by (20) and (21).

$$
\begin{aligned}
& \lambda_{s}(k+1)_{n}=\lambda_{s}(k)+T_{s}\left(\left(V_{s}(k)\right)_{n}+R i_{s}(k)\right)(20) \\
& i_{s}(k+1)_{n}=i_{s}(k)+T_{s}\left(R_{1}\left(R_{2} \lambda_{s}(k)-R_{3} i_{s}(k)+k_{r}\left(\left(V_{s}(k)\right)_{n}+R i_{s}(k)-j \omega_{r} \lambda_{s}(k)\right)+\frac{j \omega_{r} i_{s}(k)}{R_{1}}\right)\right)
\end{aligned}
$$

Where, $\mathrm{n}$ denotes voltage vector (i.e. 0 to 36 )

By forecasting flux and current for all voltage vectors, we can forecast torque for all the active voltage vector by using (22)

$$
\left(\mathrm{T}_{\mathrm{m}}(\mathrm{k}+1)\right)_{\mathrm{n}}=\frac{3}{2} \frac{\boldsymbol{P}}{2}\left(\boldsymbol{i m a g}\left(\overline{\lambda_{\boldsymbol{s}}}(\boldsymbol{k}+\mathbf{1})_{\boldsymbol{n}} * \boldsymbol{i}_{\boldsymbol{s}}(\boldsymbol{k}+\mathbf{1})_{\boldsymbol{n}}\right)\right)
$$

\begin{tabular}{|c|c|c|c|c|}
\hline VSI-1 & VSI-2 & & \multicolumn{2}{|c|}{ Realization } \\
\hline $\begin{array}{c}\left(\mathrm{S}_{\mathrm{a}}, \mathrm{S}_{\mathrm{b}}\right. \\
\left.\mathrm{S}_{\mathrm{c}}\right)\end{array}$ & $\left(\mathrm{S}_{\mathrm{a}}{ }^{\prime}, \mathrm{S}_{\mathrm{b}}{ }^{\prime}, \mathrm{S}_{\mathrm{c}}{ }^{\prime}\right)$ & $\mathrm{V}_{\mathrm{s}}$ & $\mathrm{V}_{\alpha}$ & $\mathrm{V}_{\beta}$ \\
\hline$(0,0,0)$ & $(0,0,0)$ & $\mathrm{V}_{0}$ & 0 & 0 \\
\hline$(1,0,0)$ & $(1,0,0)$ & $\mathrm{V}_{1}$ & $\mathrm{~V}_{\mathrm{dc}}(2 / 9)$ & 0 \\
\hline$(1,1,0)$ & $(1,1,0)$ & $\mathrm{V}_{2}$ & $\mathrm{~V}_{\mathrm{dc}}(1 / 9)$ & $(1.732 / 9) \mathrm{V}_{\mathrm{dc}}$ \\
\hline$(0,1,0)$ & $(0,1,0)$ & $\mathrm{V}_{3}$ & $\begin{array}{l}\mathrm{V}_{\mathrm{dc}}(- \\
1 / 9)\end{array}$ & $(1.732 / 9) \mathrm{V}_{\mathrm{dc}}$ \\
\hline$(0,1,1)$ & $(0,1,1)$ & $\mathrm{V}_{4}$ & $\begin{array}{l}\mathrm{V}_{\mathrm{dc}}(- \\
2 / 9)\end{array}$ & 0 \\
\hline$(0,0,1)$ & $(0,0,1)$ & $\mathrm{V}_{5}$ & $\begin{array}{l}\mathrm{V}_{\mathrm{dc}}(- \\
1 / 9) \\
\end{array}$ & $(-1.732 / 9) \mathrm{V}_{\mathrm{dc}}$ \\
\hline$(1,0,1)$ & $(1,0,1)$ & $\mathrm{V}_{6}$ & $\mathrm{~V}_{\mathrm{dc}}(1 / 9)$ & $(-1.732 / 9) \mathrm{V}_{\mathrm{dc}}$ \\
\hline$(1,0,0)$ & $(1,1,1)$ & $\mathrm{V}_{7}$ & $\mathrm{~V}_{\mathrm{dc}}(4 / 9)$ & 0 \\
\hline$(1,0,0)$ & $(1,0,1)$ & $\mathrm{V}_{8}$ & $\mathrm{~V}_{\mathrm{dc}}(1 / 3)$ & $(1.732 / 9) \mathrm{V}_{\mathrm{dc}}$ \\
\hline$(1,1,0)$ & $(1,1,1)$ & $\mathrm{V}_{9}$ & $\mathrm{~V}_{\mathrm{dc}}(2 / 9)$ & $(3.4642 / 9) \mathrm{V}_{\mathrm{dc}}$ \\
\hline$(0,1,0)$ & $(0,1,1)$ & $\mathrm{V}_{10}$ & 0 & $(3.4642 / 9) \mathrm{V}_{\mathrm{dc}}$ \\
\hline$(0,1,0)$ & $(1,1,1)$ & $\mathrm{V}_{11}$ & $\begin{array}{l}\mathrm{V}_{\mathrm{dc}}(- \\
2 / 9)\end{array}$ & $(3.4642 / 9) \mathrm{V}_{\mathrm{dc}}$ \\
\hline$(0,1,0)$ & $(1,1,0)$ & $\mathrm{V}_{12}$ & $\begin{array}{l}\mathrm{V}_{\mathrm{dc}}(- \\
1 / 3)\end{array}$ & $(1.732 / 9) \mathrm{V}_{\mathrm{dc}}$ \\
\hline$(0,1,1)$ & $(1,1,1)$ & $\mathrm{V}_{13}$ & $\begin{array}{l}\mathrm{V}_{\mathrm{dc}}(- \\
4 / 9)\end{array}$ & 0 \\
\hline$(0,0,1)$ & $(1,0,1)$ & $\mathrm{V}_{14}$ & $\begin{array}{l}\mathrm{V}_{\mathrm{dc}}(- \\
1 / 3)\end{array}$ & $(-1.732 / 9) \mathrm{V}_{\mathrm{dc}}$ \\
\hline$(0,0,1)$ & $(1,1,1)$ & $\mathrm{V}_{15}$ & $\begin{array}{l}\mathrm{V}_{\mathrm{dc}}(- \\
2 / 9)\end{array}$ & $(-3.464 / 9) V_{d c}$ \\
\hline$(0,0,1)$ & $(0,1,1)$ & $\mathrm{V}_{16}$ & 0 & $(-3.464 / 9) \mathrm{V}_{\mathrm{dc}}$ \\
\hline$(1,0,1)$ & $(1,1,1)$ & $\mathrm{V}_{17}$ & $\operatorname{Vdc}(2 / 9)$ & $(-3.464 / 9) \mathrm{V}_{\mathrm{dc}}$ \\
\hline$(1,0,0)$ & $(1,1,0)$ & $\mathrm{V}_{18}$ & $\mathrm{~V}_{\mathrm{dc}}(1 / 3)$ & $(-1.732 / 9) \mathrm{V}_{\mathrm{dc}}$ \\
\hline$(1,0,0)$ & $(0,1,1)$ & $\mathrm{V}_{19}$ & $\mathrm{~V}_{\mathrm{dc}}(2 / 3)$ & 0 \\
\hline$(1,0,0)$ & $(0,0,1)$ & $\mathrm{V}_{20}$ & $\mathrm{~V}_{\mathrm{dc}}(5 / 9)$ & $(1.732 / 9) \mathrm{V}_{\mathrm{dc}}$ \\
\hline$(1,1,0)$ & $(0,1,1)$ & $\mathrm{V}_{21}$ & $\mathrm{~V}_{\mathrm{dc}}(4 / 9)$ & $(3.4642 / 9) \mathrm{V}_{\mathrm{dc}}$ \\
\hline$(1,1,0)$ & $(0,0,1)$ & $\mathrm{V}_{22}$ & $\mathrm{~V}_{\mathrm{dc}}(1 / 3)$ & $(1.732 / 3) \mathrm{V}_{\mathrm{dc}}$ \\
\hline$(1,1,0)$ & $(1,0,1)$ & $\mathrm{V}_{23}$ & $\mathrm{~V}_{\mathrm{dc}}(1 / 9)$ & $(1.732 / 3) \mathrm{V}_{\mathrm{dc}}$ \\
\hline$(0,1,0)$ & $(0,0,1)$ & $\mathbf{V}_{24}$ & $\mathrm{~V}_{\mathrm{dc}}(-$ & $(1.732 / 3) \mathrm{V}_{\mathrm{dc}}$ \\
\hline
\end{tabular}

Table 1: Active Switching States and realization 


\begin{tabular}{|c|c|c|c|c|}
\hline & & & $1 / 9)$ & \\
\hline$(0,1,0)$ & $(1,0,1)$ & $\mathrm{V}_{25}$ & $\begin{array}{c}\mathrm{V}_{\mathrm{dc}}(- \\
1 / 3)\end{array}$ & $(1.732 / 3) \mathrm{V}_{\mathrm{dc}}$ \\
\hline$(0,1,0)$ & $(1,0,0)$ & $\mathrm{V}_{26}$ & $\begin{array}{c}\mathrm{V}_{\mathrm{dc}}(- \\
4 / 9)\end{array}$ & $(3.464 / 9) \mathrm{V}_{\mathrm{dc}}$ \\
\hline$(0,1,1)$ & $(1,0,1)$ & $\mathrm{V}_{27}$ & $\begin{array}{c}\mathrm{V}_{\mathrm{dc}}(- \\
5 / 9)\end{array}$ & $(1.732 / 9) \mathrm{V}_{\mathrm{dc}}$ \\
\hline$(0,1,1)$ & $(1,0,0)$ & $\mathrm{V}_{28}$ & $\begin{array}{c}\mathrm{V}_{\mathrm{dc}}(- \\
2 / 3)\end{array}$ & 0 \\
\hline$(0,1,1)$ & $(1,1,0)$ & $\mathrm{V}_{29}$ & $\begin{array}{c}\mathrm{V}_{\mathrm{dc}}(- \\
5 / 9)\end{array}$ & $(-1.732 / 9) \mathrm{V}_{\mathrm{dc}}$ \\
\hline$(0,0,1)$ & $(1,0,0)$ & $\mathrm{V}_{30}$ & $\begin{array}{c}\mathrm{V}_{\mathrm{dc}}(- \\
4 / 9)\end{array}$ & $(-3.464 / 9) \mathrm{V}_{\mathrm{dc}}$ \\
\hline$(0,0,1)$ & $(1,1,0)$ & $\mathrm{V}_{31}$ & $\begin{array}{c}\mathrm{V}_{\mathrm{dc}}(- \\
1 / 3)\end{array}$ & $(-1.732 / 3) \mathrm{V}_{\mathrm{dc}}$ \\
\hline$(0,0,1)$ & $(0,1,0)$ & $\mathrm{V}_{32}$ & $\begin{array}{c}\mathrm{V}_{\mathrm{dc}}(- \\
1 / 9)\end{array}$ & $(-1.732 / 3) \mathrm{V}_{\mathrm{dc}}$ \\
\hline$(1,0,1)$ & $(1,1,0)$ & $\mathrm{V}_{33}$ & $\mathrm{~V}_{\mathrm{dc}}(1 / 9)$ & $(-1.732 / 3) \mathrm{V}_{\mathrm{dc}}$ \\
\hline$(1,0,1)$ & $(0,1,0)$ & $\mathrm{V}_{34}$ & $\mathrm{~V}_{\mathrm{dc}}(1 / 3)$ & $(-1.732 / 3) \mathrm{V}_{\mathrm{dc}}$ \\
\hline$(1,0,1)$ & $(0,1,1)$ & $\mathrm{V}_{35}$ & $\mathrm{~V}_{\mathrm{dc}}(4 / 9)$ & $(-3.464 / 9) \mathrm{V}_{\mathrm{dc}}$ \\
\hline$(1,0,0)$ & $(0,1,0)$ & $\mathrm{V}_{36}$ & $\mathrm{~V}_{\mathrm{dc}}(5 / 9)$ & $(-1.732 / 9) \mathrm{V}_{\mathrm{dc}}$ \\
\hline
\end{tabular}

\section{Step 3: The Formulation of Cost Function}

In this simplified PTC, the costfunction is given with active and reactive torque control objectives. The Reactive torque control objective is similar to flux control and the cost function is given by (23).

$G_{n}=\left|T_{m}^{*}-T_{m}(k+1)_{n}\right|+\left|T_{r}^{*}-\right| T_{r}(k+1)_{n}||$

In this reactive torque is obtained from the flux PI controller and flux in the machine is analogous to reactive torque. The reactive torque is given by

$\mathrm{T}_{\mathrm{r}}=\frac{3}{2} \frac{P}{2}\left(\boldsymbol{r e a l}\left(\overline{\lambda_{s}} * \mathrm{i}_{\mathrm{s}}\right)\right)$

Reactive torque can be forecasted one step ahead for all the active voltage vectors

$\left(T_{r}(k+1)\right)_{n}=\frac{3}{2} \frac{P}{2}\left(\operatorname{real}\left(\overline{\lambda_{s}}(k+1)_{n} * i_{s}(k+1)_{n}\right.\right.$

From (23), the first control objective serve as electromagnetic torque and second control objective serve as reactive torque control which represents flux control. So the two control objectives are in same units, the weighting factor in cost function is completely removed.

\section{Step 4: Nearest Voltage Vector Selection}

In simplified PTC of OEWIM drive, the most advantageous voltage vector is the one which gives small cost function value. For selecting optimal voltage vector, the cost function (23) should be resolved for the selected 37 vectors in each period.In the control process calculated burden can be reduced by limiting the number of forecasted voltage vectors, which is obtained by selecting the vector atmost to optimum voltage vector. This is done by selecting minimum one from small vector group and four from medium vector and four from large vector groupWith this only 12 vectors are forecasted including null vector. 


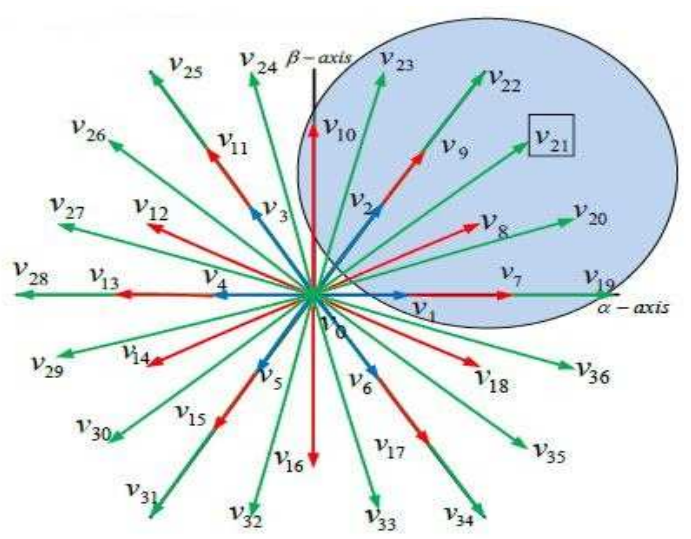

Figure 3: Available limited forecasting voltage vectors selection for latersample interval when the instant optimal voltage vector is $V_{21}$

The overall control steps involved in predicting voltage vectors is represented in flow graph

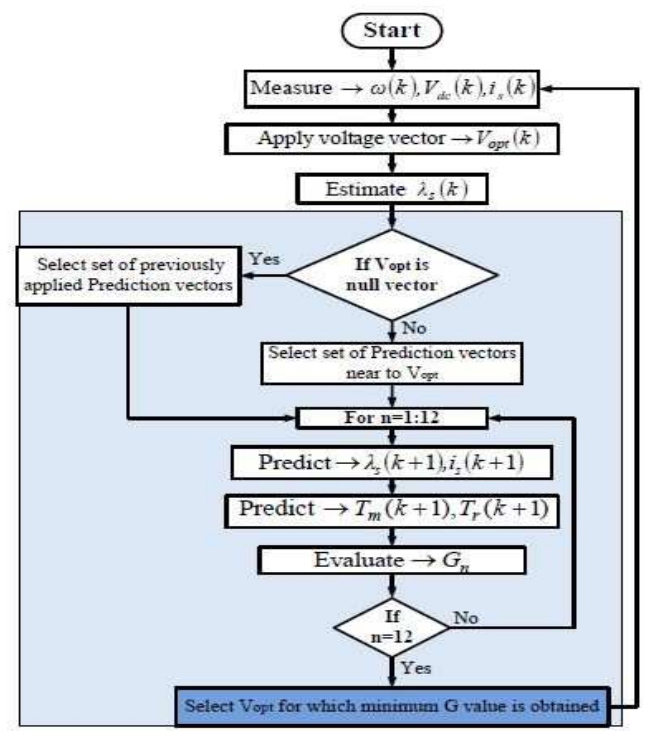

Figure 4: Simplified PTC Flow graph

\section{SIMPLIFIED PTC USING ANFIS CONTROLLER}

The adaptive neuro-fuzzy inference system (ANFIS) is the ANN(artificial neural network) which is the sequence of Fuzzy Systems and Neural Networks. The fuzzy inference system constitutes a fuzzy model which was given by Takagi-Sugeno to formalize a precise access to spawn the fuzzy rules from the input - output dataset. ANFIS block diagram is shown in Fig5.
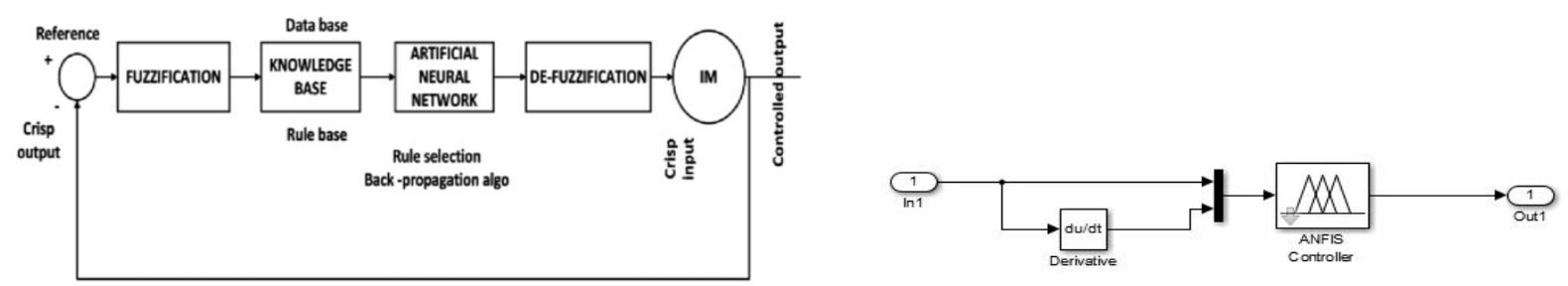

Figure 5: ANFIS block diagram for generating torque 
In this paper consider two inputs and 3 fuzzified values. The fuzzified values are positive, zero and negative. With three fuzzified values, 9 rules are framed in fuzzy system. Among 9 rules, the optimum one is fired and de-fuzzified output becomes the output neuron. The two inputs are speed error and change in speed error. The following figure shows the input membership functions.

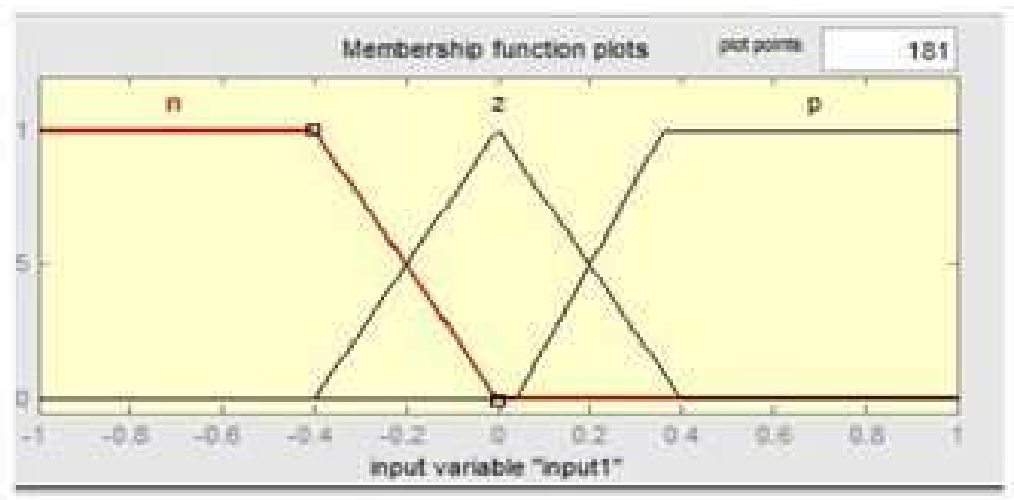

a) Input-1

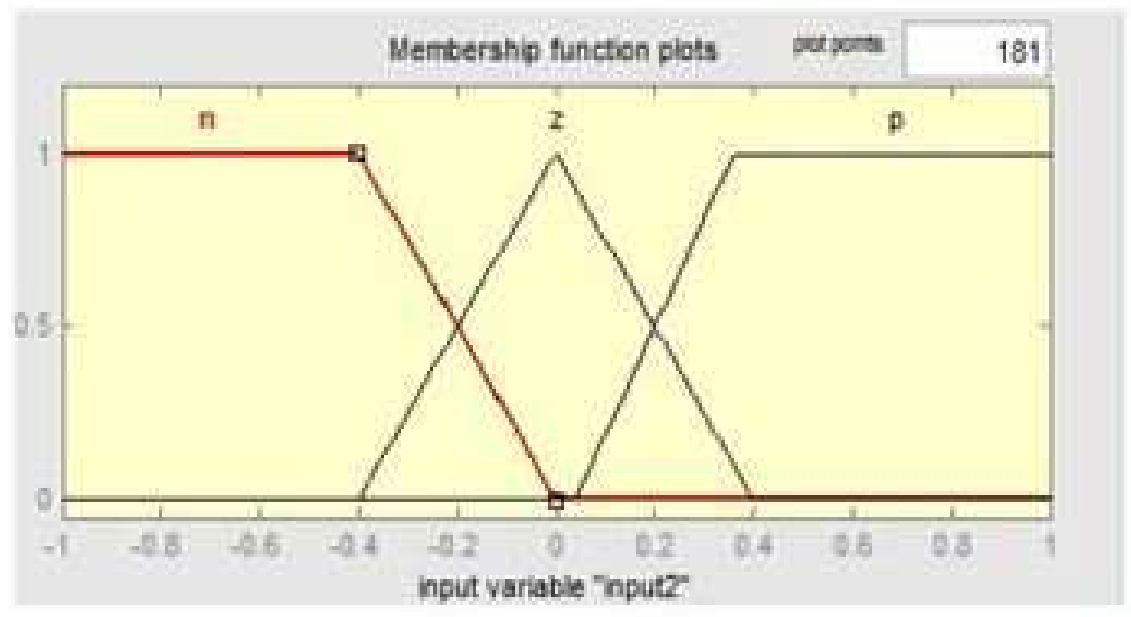

b) Input-2

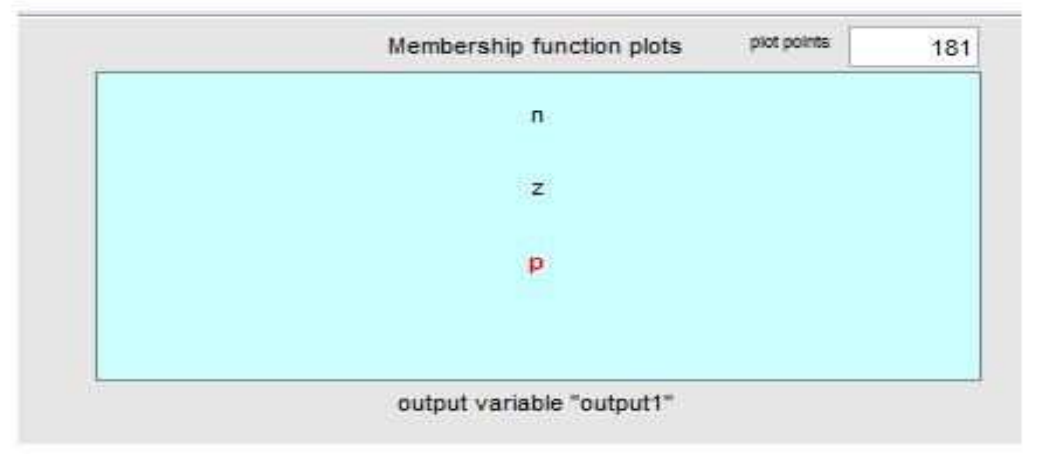

c) Output

Figure 6: Membership functions of ANFIS

a) Input-1 is the speed error b) Input-2 is change in speed error c) output 


\section{A Simulation Diagram of Simplified PTC using ANFIS}

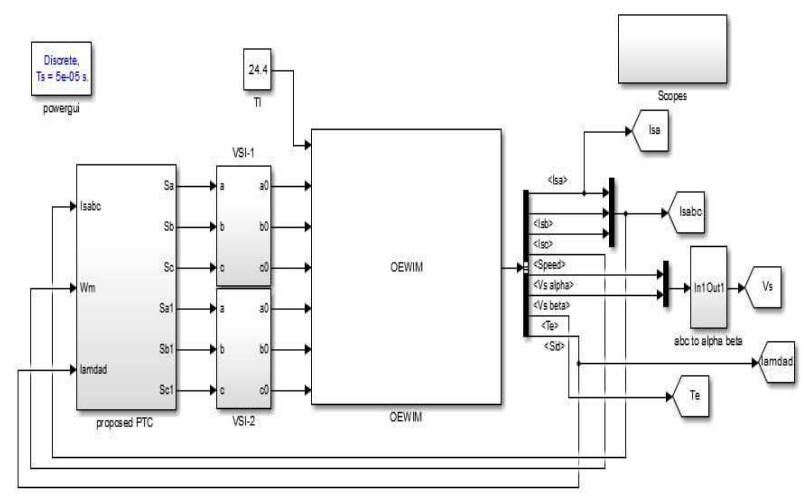

Figure 7: Simulation diagram of simplified PTC using ANFIS controller

\section{SIMULATION RESULTS}

The motor drive parameters are represented in table-2. The simplified PTC using PI and ANFIS controller are implemented through MATLAB/Simulink software. The modeling of OEWIM drive is done using mathematical equations (1) to (12). Here, the combined dc link voltage is taken as 500v. The dc link voltage for VSI-1 is 333.33v and for VSI-2 it is $166.67 \mathrm{v}$.

Table 2: OEWIM drive parameters

\begin{tabular}{|l|c|}
\hline \multicolumn{1}{|c|}{ Motor Parameter } & Quantity \\
\hline Poles $(\mathrm{P})$ & 4 \\
\hline Rated torque & $24.5 \mathrm{Nm}$ \\
\hline Rated speed & $1440 \mathrm{RPM}$ \\
\hline Rated power & $3.7 \mathrm{KW}$ \\
\hline Inertia $(\mathrm{J})$ & $0.031 \mathrm{Kg}-\mathrm{m}^{2}$ \\
\hline Stator Inductance $\left(\mathrm{L}_{\mathrm{s}}\right)$ & $0.54 \mathrm{H}$ \\
\hline Stator Resistance $\left(\mathrm{R}_{\mathrm{s}}\right)$ & 1.8 \\
\hline Mutual Inductance $\left(\mathrm{L}_{\mathrm{m}}\right)$ & $0.512 \mathrm{H}$ \\
\hline Rotor Inductance $\left(\mathrm{L}_{\mathrm{r}}\right)$ & $0.54 \mathrm{H}$ \\
\hline Rotor Resistance $\left(\mathrm{R}_{\mathrm{r}}\right)$ & 0.8 \\
\hline
\end{tabular}

Simulations of simplified PTC for two inverters fed OEWIM using PI and ANFIS controller are simulated. Simulation results of simplified PTC using PI and ANFIS controller are shown in Fig.8 and Fig.9 respectively. Up to the simulation time of $2 \mathrm{sec}$, the speed to be compared with the motor speed is set to $=150 \mathrm{rad} / \mathrm{sec}$. During this period the motor shows steady state forward speed, flux, torque and current response. At the instant of $2 \mathrm{sec}$, there is step change in speed from $+150 \mathrm{rad} / \mathrm{sec}$ to $-150 \mathrm{rad} / \mathrm{sec}$. During this period, the dynamic response is observed. After $2.15 \mathrm{sec}$, the speed of motor reaches $-150 \mathrm{rad} / \mathrm{sec}$ and maintains constant speed $-150 \mathrm{rad} / \mathrm{sec}$ it indicates reverse motoring operation. The steady state current, reverse speed, flux and torqueis observed. 

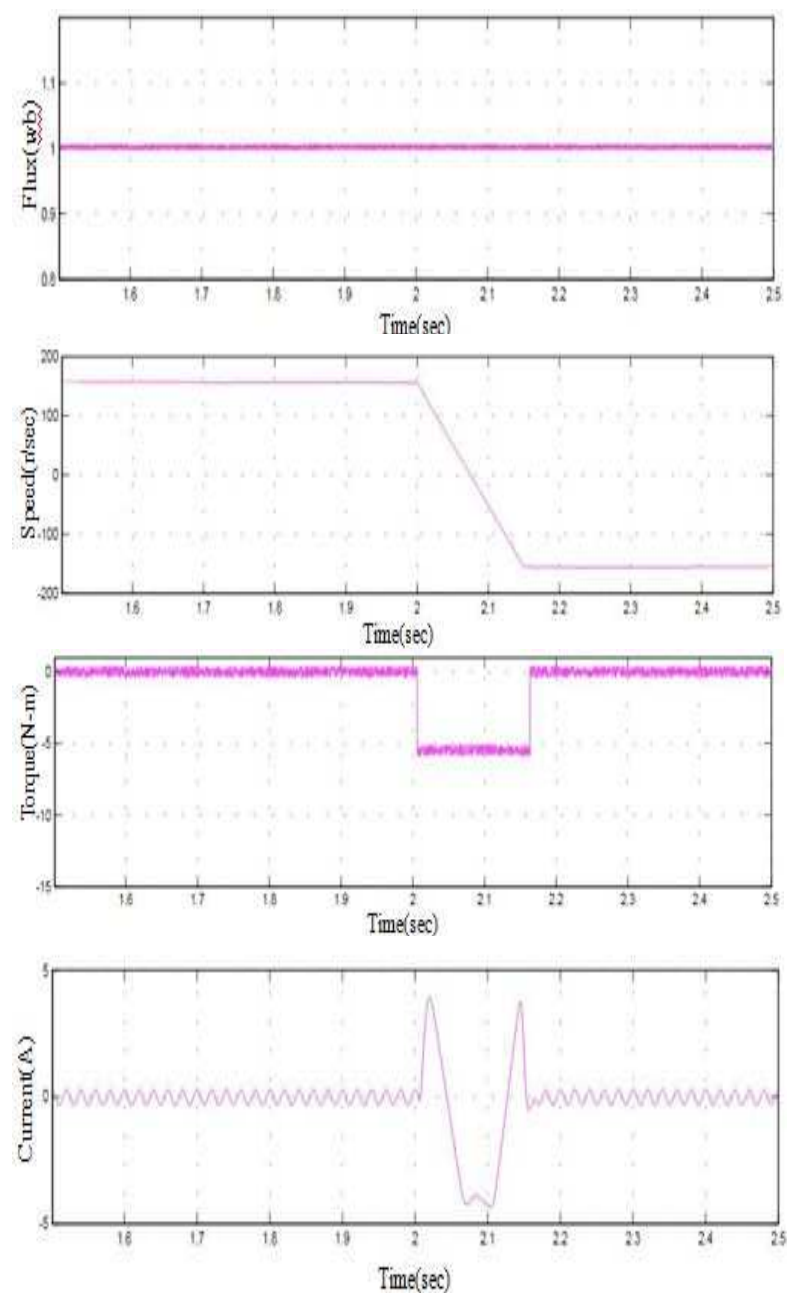

Figure 8: Flux, speed, torque and current response of OEWIM drive by simplified PTC with PI controller
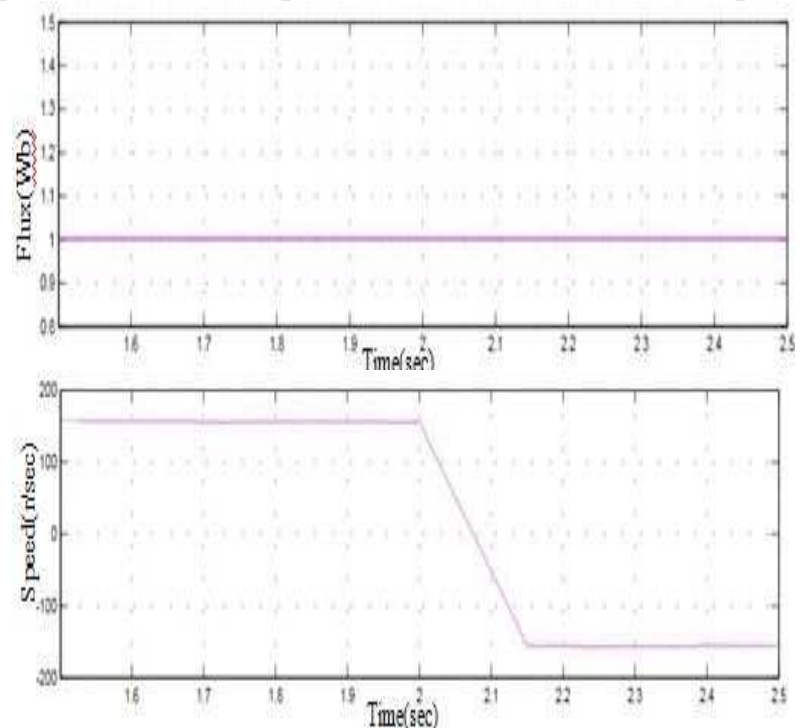

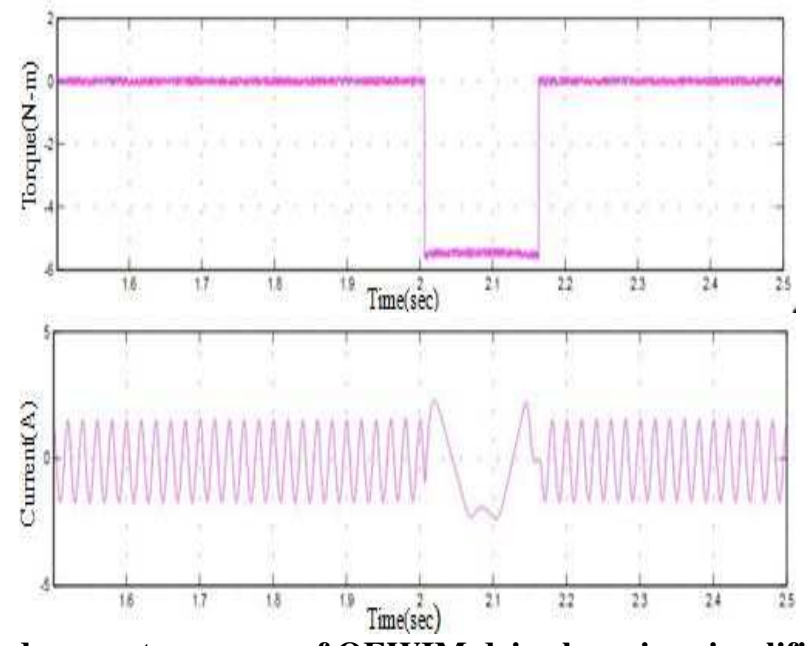

Figure 9: Flux, speed torque and current response of OEWIM drive by using simplified PTC with ANFIS controller

\section{CONCLUSIONS}

This paper introduces simplified PTC for dual inverter fed OEWIM using ANFIS controller providing improved torque and flux response. The number of forecasting voltage vectors are limited based on the selection of nearby voltage vector to optimum voltage vector. Due to the selection of nearby voltage vector computational burden is reduced. Due to the sudden change in load, the transient current will be high in the simplified PTC fed OEWIM drive with PI controller compared to the ANFIS controller. The torque and flux ripples will be minimum with ANFIS controller. The smooth variation in speed and time taken to reach steady state speed will be less with the ANFIS controller.

\section{REFERENCES}

1. S. Kouro, M. Malinowski, K. Gopakumar, J. Pou, L. G. Franquelo, B. Wu, et al., "Recent Advances and Industrial Applications of Multilevel Converters," IEEE Trans. Ind. Electron.,Aug. 2010.

2. CHOWDARY, A. HEMANT, and PV RAMANA RAO. "ADAPTIVE NEURO-FUZZY BASED PSS FOR MULTI MACHINE SYSTEMS. "International Journal of Electrical and Electronics Engineering Research (IJEEER) 3.2, Jun 2013, 223-232

3. Krishna Kumar Gupta, AlekhRanjan, Pallavee Bhatnagar, Lalit Kumar Sahu, and Shailendra Jain, "Multilevel Inverter Topologies with Reduced Device Count: A Review" IEEE Trans. Power Electron.,Jan. 2016.

4. S. Lakhimsetty, N. Surulivel and V. T. Somasekhar, "Improvised SVPWM Strategies for an Enhanced Performance for a FourLevel Open-End Winding Induction Motor Drive," in IEEE Transactions on Industrial Electronics, April 2017.

5. Naga Surya Prakash M and S. Srinivas, "Field Oriented Control of an Open End Winding Induction Machine with zero Common Mode Voltage," in National Power Electronics Conference college of engineering Pune 2017.

6. SALIH, HASAN WAHHAB, AK BHARDWAJ, and SURYA PRAKASH. "LOAD FREQUENCY CONTROL OF HYBRID SYSTEM USING INDUSTRIAL CONTROLLER AND IMPLEMENT FUZZY CONTROLLER PRACTICALLY USING PLC."International Journal of Electrical and Electronics Engineering Research (IJEEER) 3. 4, Oct 2013, 187-204

7. Takashi and T. Noguchi, “A new quick-response and high-efficiency control of an induction motor,” IEEE Trans. on Industry Applications, vol. 22, no.5, 1986, pp. 820-827.

8. Kyo-Beum Lee, Joong-Ho Song, Ick Choy and Ji-Yoon Yoo, "Torque ripple reduction in DTC of induction motor driven by three-level inverter with low switching frequency”, IEEE Trans. Power Electronics, 2002. 
9. Tiwari, Pratibha, and C. K. Shukla. "A Fuzzy Based Duty Ratio Approach To Torque Ripple Minimization Strategy For Direct Torque Control Of Induction Motor." International Journal of Electrical and Electronics Engineering Research (IJEEER): 1928.

10. K.-K. Shyu, J.-K. Lin, V.-T. Pham, M.-J. Yang, and T.-W. Wang, "Global minimum torque ripple design for direct torque control of induction motor drives,” IEEE Trans. Ind. Electron.,Sep. 2010.

11. R. Ramchand, K. Gopakumar,C. Patel, K. Sivakumar,A.Das, and H. Abu-Rub, "Online computation of hysteresis boundary for constant switching frequency current-error space-vector-based hysteresis controller for VSI fed IM drives," IEEE Trans. Power Electron., Mar. 2012.

12. Hegde, Sharat S., SagarChakole, and VatsalVora. "Development of Self Balancing Robot With PID Control." International Journal of Robotics Research and Development (IJRRD) 7.1 (2017): 1-6.

13. Vinod B. R., M. R. Baiju, "Direct Torque Control implemented on a Three-level Open-end winding Induction motor drive," power electronics research laboratory, Kerala, 2016.

14. A. Linder and R. Kennel, "Model Predictive Control for Electrical Drives," in Power Electronics Specialists Conference, 2005. PESC '05. IEEE 36th, 2005.

15. Jose Rodriguez; Patricio Cortes, "Predictive Control of Induction Machines, "in Predictive Control of Power Converters and Electrical Drives, 1, Wiley-IEEE Press, 2012, pp.115-132.

\section{AUTHORS PROFILE}

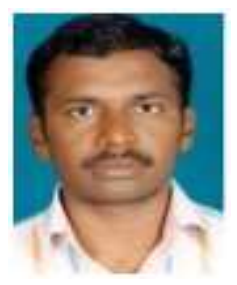

Dr. M. ANKARAO, He received his Bachelor of Electrical \& Electronics engineering degree from the Andhra University, vishakapattanam, A.P in 2006. In 2010, he received M.Tech degree from JNTU Anantapuramu in Power and Industrial Drives. He received his Ph.D in 2020 from JNT University Ananthapuramu, India. He currently serves as assistant professor at JNTUA College of Engineering, Electrical Department, and Ananthapuramu, India. He has a 10 years of teaching experience. His research areas include Electrical Machines, Electrical Drives and Power Electronics.

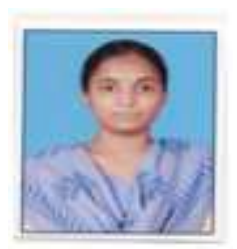

L. SIREESHA, graduated fromY.S.R Engineering College of YVU, Kadapa, India in 2018, from the Electrical and Electronics Engineering. She is currently pursuing her Master's Degree in Power \&Industrial Drives specialization from the Electrical department from JNTUA college of Engineering, Ananthapuramu, India, in 2020. In fulfillmentof Bachelor's degree she done Design \& Simulation of Voltage Sag/Swell compensation using DVRbased on PI and Fuzzy Controller. Her research interests are Model Predictive Control Schemes for Induction motors and applications of Multi level Inverters. 


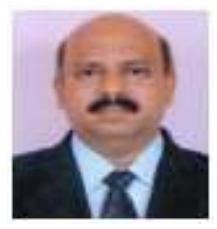

Prof M. VIJAYA KUMAR graduated in 1988 from the S.V. University, Tirupathi, A.P, India. HerecievedM.Tech degree in 1990 from the Regional Engineering College (NITW), Warangal, India. He also received his Doctorate from the Jawaharlal Nehru Technological University, Hyderabad, India in 2000. Currently he is working as a Professor in Electrical and Electronics Engineering and also as the Director of Academic \& Planning, as JNTUniversityAnantapur Registrar, A.P, India. He has 30 years of experience in teaching. His areas of focus includes Electrical Machines, Electrical Drives, Microprocessors and Power Electronics.

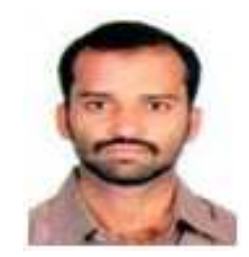

Dr. J. SREENIVASULU received his B.Tech degree in Electrical and Electronics engineering in 2007. He received his M.Tech in Electrical Power System in 2009. He received his Ph.D from JNT University, Anantapur, A.P, India, in 2019. Currently he is working as Assistant Professor in EEE Department, JNTUA college of Engineering, Anantapuramu, A.P, India. His research interest areas are Electrical Power Systems, Reliability Engineering, Drives and Restructured Power Systems.. He has teaching experience of 9 years. 

